\title{
Evidence That Tumor Necrosis Factor Plays a Pathogenetic Role in the Paraneoplastic Syndromes of Cachexia, Hypercalcemia, and Leukocytosis in a Human Tumor in Nude Mice
}

\author{
Toshiyuki Yoneda, ${ }^{\star *}$ Maria A. Alsina, ${ }^{*}$ Jeffery B. Chavez, ${ }^{*}$ Lynda Bonewald, ${ }^{*}$ Riko Nishimura, ${ }^{\star}$ and Gregory R. Mundy* \\ *Division of Endocrinology and Metabolism, Department of Medicine, The University of Texas Health Science Center at San Antonio, \\ San Antonio, Texas 78284-7877; and ${ }^{\ddagger}$ Second Department of Oral and Maxillofacial Surgery, Faculty of Dentistry, \\ Osaka University, Osaka 565, Japan
}

\begin{abstract}
Recently, we have established a human squamous cell carcinoma of the maxilla (called MH-85) associated with hypercalcemia, leukocytosis, and cachexia in culture. MH-85 tumor cells caused the same paraneoplastic syndromes in tumor-bearing nude mice. We found that there was a sixfold increase in splenic size in MH-85 tumor-bearing mice. This increase paralleled tumor growth and was reversed by surgical removal of the tumor. Splenectomy in nude mice 1 wk before or 6 wk after tumor inoculation resulted in a decrease in tumor growth, and impairment of hypercalcemia, leukocytosis, and cachexia. In MH-85 tumor-bearing animals that had been pretreated by splenectomy, intravenous injection of fresh normal spleen cells caused an immediate reversal of leukocytosis, hypercalcemia, and cachexia. Since the presence of cachexia in both the patient and the mice carrying the tumor suggested tumor necrosis factor (TNF) may be overproduced, we injected polyclonal neutralizing antibodies raised against murine TNF into tumor-bearing mice. There was a rapid and reproducible decrease in blood ionized calcium, accompanied by suppression of osteoclast activity. No changes in blood ionized calcium were seen in mice injected with normal immune sera. In addition, there was an increase in body weight and decrease in white cell count. Plasma immunoreactive TNF was increased almost fourfold in tumor-bearing nude mice compared with control nude mice. Although TNF activity was undetectable in MH-85 culture supernatants, cells of the macrophage lineage, including spleen cells, released increased amounts of TNF when cultured with $\mathrm{MH}-85$ tumor-conditioned media. These results suggest that splenic cytokines such as TNF may influence the development of the paraneoplastic syndromes of hypercalcemia, leukocytosis, and cachexia in these animals, as well as tumor growth. They also show that paraneoplastic syndromes may be due to factors produced by normal host cells stimulated by the presence of the tumor. (J. Clin. Invest. 1991. 87:977-985.) Key words: squa-
\end{abstract}

Address reprint requests to Dr. Toshiyuki Yoneda, Division of Endocrinology and Metabolism, Department of Medicine, The University of Texas Health Science Center at San Antonio, 7703 Floyd Curl Drive, San Antonio, TX 78284-7877. 1990.

Received for publication 1 May 1990 and in revised form 10 October

J. Clin. Invest.

(C) The American Society for Clinical Investigation, Inc.

0021-9738/91/03/0977/09 \$2.00

Volume 87, March 1991, 977-985 mous cell carcinoma $\bullet$ splenomegaly $\bullet$ bone resorption $\bullet$ host immune cells $\cdot$ cytokines

\section{Introduction}

Paraneoplastic syndromes are common concomitants of neoplastic disease $(1,2)$. Two of the most common are cachexia (3) and hypercalcemia (4). In addition to cachexia and hypercalcemia, leukocytosis is also a relatively common paraneoplastic syndrome (5). In recent years, a number of studies have noted the association between leukocytosis and hypercalcemia (6$10)$, and several factors including colony-stimulating factors for granulocytes (G-CSF), ' for granulocyte-macrophages (GMCSF), and for macrophages (M-CSF) and bone resorbing factors (7-9) have been implicated in the pathogenesis of the leukocytosis-hypercalcemia syndrome.

Recently, we have established a cell line (MH-85) from a human squamous cell carcinoma of the maxilla associated with cachexia and the leukocytosis-hypercalcemia syndrome. When inoculated into nude mice, $\mathrm{MH}-85$ cells induced formation of a squamous cell carcinoma with similar histological characteristics to those of the patient. In these MH-85 tumor-bearing nude mice, body weight was markedly reduced and the mice developed leukocytosis and hypercalcemia. In parallel with the development of these paraneoplastic syndromes, the mice also manifested marked splenomegaly. Although it has been reported that splenomegaly is frequently observed in tumorbearing animals with leukocytosis (11-15), the relationship between leukocytosis and splenomegaly has not been elucidated. Furthermore, little is known about the relationship between splenomegaly and cachexia or hypercalcemia. To examine the relationship between these paraneoplastic syndromes and the splenomegaly, we assessed the effects of splenectomy on the development of these paraneoplastic syndromes in MH-85 tumor-bearing mice. We found that splenectomy led to a striking decrease in the severity of the paraneoplastic syndromes, and that this effect could be reversed by inoculation of the tumorbearing animals with normal spleen cells. Moreover, we found that the effects of splenectomy could be mimicked by injection of neutralizing polyclonal antibodies to murine tumor necrosis factor (TNF Ab). TNF immunoreactivity was increased in the

1. Abbreviations used in this paper: CM, culture supernatants; CSF, colony-stimulating factor; G-CSF, granulocyte CSF; GM-CSF, granulocyte-macrophage-CSF; M-CSF, macrophage-CSF; NIS, nonimmune serum; PMA, phorbol myristate acetate; TNF, tumor necrosis factor; TNF Ab, rabbit polyclonal anti-mouse TNF anti-serum. 
circulation of tumor-bearing animals, and although tumor cells did not release detectable TNF biological activity, tumor cell conditioned media stimulated cells of the monocyte-macrophage lineage, including spleen cells, to release TNF.

\section{Methods}

Cell culture. MH-85 cells were isolated from a squamous cell carcinoma obtained at biopsy from a patient who manifested marked cachexia, hypercalcemia, leukocytosis, and splenomegaly (10) by explant outgrowth technique (16). The cells were cultured in alpha minimal essential medium (Hazleton Biologics, Inc., Lenexa, KS) supplemented with $10 \%$ heat-inactivated FCS (HyClone Laboratories Sterile Systems Inc., Logan, UT) and 1\% penicillin-streptomycin solution (Gibco Laboratories, Grand Island, NY). As a control, another human squamous cell carcinoma of the maxilla (OKK) that was not associated with any of these paraneoplastic syndromes was also established in culture.

Inoculation of MH-85 tumor cells into nude mice. Two pieces of MH-85 tumor $(3 \times 3 \mathrm{~mm}$ in size $)$ or cells $\left(5 \times 10^{6}\right.$ in $0.1 \mathrm{ml}$ calciummagnesium-free phosphate-buffered saline [PBS[-]) were inoculated subcutaneously in the right dorsal portion of 4-6 wk-old male Balb c/nu/nu mice (Harlan Sprague Dawley, Inc., Indianapolis, IN) by a trocar or 27-gauge needle, respectively. Animals were fed ad lib. on autoclaved diet (Teklad-LH-485, calcium $0.83 \mathrm{mg} / \mathrm{kg}$, phosphorus $0.65 \mathrm{mg} / \mathrm{kg}$, Harlan Sprague-Dawley) and tap water (acidified to $\mathrm{pH}$ 2.5). The body weights of $\mathrm{MH}-85$ tumor-bearing animals and their tumor sizes were measured once a week under anesthesia with ether. Tumor size was calculated as described (17). Tumors were excised and weighed when animals were killed. Details of this tumor-bearing nude mice model are described elsewhere (18).

Determination of blood ionized calcium $\left(\mathrm{Ca}^{2+}\right)$ and leukocyte count. $30 \mu \mathrm{l}$ of blood was drawn from the orbital plexus with calcium-titrated sodium heparinate-coated tubes (Corning, Halstead, Essex, UK) under anesthesia with ether, and adjusted for $\mathrm{pH}$ by an internal algorithm in the machine (19). $\mathrm{Ca}^{2+}$ was determined using a Ciba-Corning calciumpH analyzer (model 634; Corning Medical, Medfield, MA). Normal ranges of $\mathrm{Ca}^{2+}$ in nude mice determined using this analyzer are between 0.85 and $1.29 \mathrm{mmol} / \mathrm{liter} .100 \mu \mathrm{l}$ of blood was also collected into polypropylene microsample tubes (Kew Scientific Inc., Columbus, $\mathrm{OH}$ ) and centrifuged to sediment blood cells. Precipitated blood cells were suspended in erythrocyte-lysing buffer $(13 \mathrm{mM}$ Tris- $\mathrm{HCl}, \mathrm{pH} 7.65$ in $0.75 \% \mathrm{NH}_{4} \mathrm{Cl}$ ), incubated for $5 \mathrm{~min}$ at $37^{\circ} \mathrm{C}$, resuspended in $\mathrm{PBS}(-)$, and counted on a hemocytometer.

Spleen index. At the appropriate time after tumor implantation, MH-85 tumor-bearing nude mice were killed and their spleens and tumors were removed. Weights of the spleens and carcass were measured. Spleen index was expressed as spleen wet $\mathrm{wt}(\mathrm{mg}) /$ carcass wt (g).

Tumor excision. MH-85 tumors were aseptically excised from animals under anesthesia with Nembutal $(0.05 \mathrm{mg} / \mathrm{g}$ body wt). At the appropriate time after surgery, $\mathrm{Ca}^{2+}$ and leukocyte count were determined. The animals were then killed and their spleens were excised and weighed.

$T N F$ radioimmunoassay. Heparinized plasma was assayed for murine TNF by radioimmunoassay as described previously (20). The samples $(250 \mu \mathrm{l})$ were incubated with $100 \mu \mathrm{l} \mathrm{TNF} \mathrm{Ab}$ overnight at $4^{\circ} \mathrm{C}$ and then with $100 \mu \mathrm{l}{ }^{125} \mathrm{I}$-murine TNF $\alpha(10,000 \mathrm{cpm})$ overnight at $4^{\circ} \mathrm{C}$, precipitated with goat anti-rabbit IgG (Cappel, Organon Teknika, West Chester, PA) for $1 \mathrm{~h}$ at room temperature and centrifuged at $2,500 \mathrm{~g}$ for $30 \mathrm{~min}$. The radioactivity in the pellets was counted in a gamma counter. Purified murine TNF $\alpha$ and TNF Ab were kindly provided by Dr. Tony Chen, Genentech, South San Francisco, CA. The TNF Abs are specific for murine TNF and do not cross-react with human TNF. Recognition of circulating TNF by TNF Ab was confirmed by comparing levels of activity in the radioimmunoassay with biological activity in the $\mathbf{L} 929$ cytotoxicity assay.
Injection of TNF $A b$. At each week after tumor transplantation, $\mathrm{Ca}^{2+}$ levels of individual mice were measured as described above. At appropriate times after tumor inoculation when MH-85-bearing animals manifested severe cachexia, leukocytosis, and hypercalcemia, 0.1 $\mathrm{ml}$ of TNF $\mathrm{Ab}$ ( $\mathrm{sp}$ act, $>4 \times 10^{5}$ neutralizing $\mathrm{U} / \mathrm{ml}$, generously provided by Dr. Tony Chen) or rabbit nonimmune sera (NIS) were injected intraperitonealy into nude mice. Blood was drawn for the determination of $\mathrm{Ca}^{2+}$ levels before injection of the TNF $\mathrm{Ab}$ at 9:30 a.m. Body weight, leukocyte count, and tumor size before and after the treatment with TNF Ab were also measured.

Assessment of tumor effects on monocytic cells. Human peripheral blood monocytes were prepared as described (21). HL-60 (22) and U937 (23) cells were obtained from the American Type Culture Collection, Rockville, MD. Nude mouse spleen mononuclear cells were isolated using Histopaque (Sigma Chemical Co., St. Louis, MO) density gradient centrifugation. Elicited peritoneal macrophages from non-tumor- and $\mathrm{MH}-85$-bearing nude mice were obtained as described (24). Cells $\left(1 \times 10^{6} / \mathrm{ml}\right)$ were incubated in RPMI 1640 medium supplemented with $5 \%$ FCS in the presence of $10 \mathrm{ng} / \mathrm{ml}$ phorbol myristate acetate (PMA; Sigma) and 50\% MH-85 culture supernatants (CM). After $24 \mathrm{~h}$ incubation, the culture supernatants were harvested, centrifuged under sterile conditions, and assayed for their TNF cytotoxic activity.

TNF bioassay. TNF activity in monocytic cell $\mathrm{CM}$ was assayed by its capacity to cause cytotoxicity in indicator cells as described (25). In brief, mouse L929 fibroblasts (American Type Culture Collection) were cultured at a density of $6 \times 10^{5} / \mathrm{ml}$ in Eagle's minimal essential medium supplemented with $3 \%$ FCS in 96-well flat-bottom microtiter plates in the presence of $1 \mu \mathrm{g} / \mathrm{ml}$ actinomycin D (Sigma) and a serially diluted monocytic cell CM and recombinant human TNF (kindly provided by Dr. H. Michael Shepard, Genentech) as standard for $20 \mathrm{~h}$. At the end of culture, the plates were washed, fixed with $100 \%$ methanol, and stained with $0.5 \%$ solution of crystal violet (Sigma) in $20 \%$ ethanol. The plates were air-dried and read on Titertek Multi-scan autoreader (Flow Laboratories, Inc., McLean, VA) set for absorption at $540 \mathrm{~nm}$. One unit of TNF is defined as the amount required for $50 \%$ cell lysis. Specificity for TNF bioactivity was confirmed by the use of specific neutralizing monoclonal antibodies to TNF (also kindly provided by Dr. Shepard).

\section{Results}

Splenomegaly, hypercalcemia, leukocytosis, and cachexia in $M H-85$ tumor-bearing nude mice. Splenomegaly was found to be striking in nude mice bearing MH-85 tumors (Table I) and closely associated with tumor growth and progression of hyper-

Table I. Carcass and Tumor Weight, $\mathrm{Ca}^{2+}$, Leukocyte Count, and Splenomegaly in Tumor-bearing Animals

\begin{tabular}{lcccccc}
\hline $\begin{array}{l}\text { Nude mice } \\
\text { bearing }\end{array}$ & & $\begin{array}{c}\text { Carcass } \\
\text { weight }\end{array}$ & $\begin{array}{c}\text { Tumor } \\
\text { weight }\end{array}$ & $\mathrm{Ca}^{2+}$ & $\begin{array}{c}\text { Leukocyte } \\
\text { count }\end{array}$ & $\begin{array}{c}\text { Spleen } \\
\text { index* }\end{array}$ \\
\hline & $n$ & $g$ & $g$ & mmol/liter & $10^{3} / \mathrm{mm}^{3}$ & $\mathrm{mg} / \mathrm{g}$ \\
MH-85 & 16 & $15 \pm 1^{\ddagger}$ & $3.6 \pm 0.6$ & $2.4 \pm 0.2^{\S}$ & $336 \pm 41^{8}$ & $49 \pm 3^{\S}$ \\
OKK & 8 & $33 \pm 3$ & $3.9 \pm 0.5$ & $1.3 \pm 0.1$ & $12 \pm 2$ & $6 \pm 3$ \\
None & 8 & $32 \pm 3$ & - & $1.2 \pm 0.1$ & $8 \pm 1$ & $4 \pm 1$
\end{tabular}

Values were determined $8 \mathrm{wk}$ after tumor implantation when animals were killed and were shown as mean $\pm \mathrm{SE}$.

* Spleen index was calculated spleen wet wt $(\mathrm{mg}) /$ carcass wt $(\mathrm{g})$.

¥ Significantly smaller than non-tumor-bearing animals $(P<0.005$, Student's $t$ test).

${ }^{8}$ Significantly greater than non-tumor-bearing animals $(P<0.001)$. 
Body Weight (g)

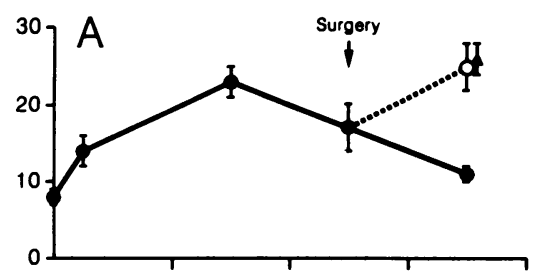

W.B.C. $\left(\times 10^{3} / \mathrm{mm}^{3}\right)$

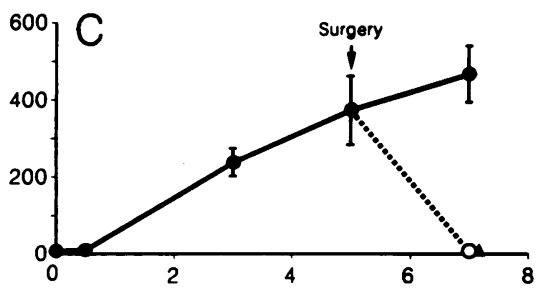

$\mathrm{Ca}^{2+}(\mathrm{mmol} / \mathrm{L})$

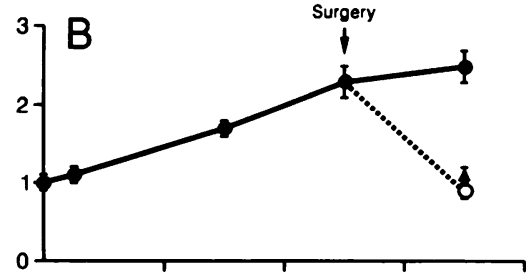

Spleen Index

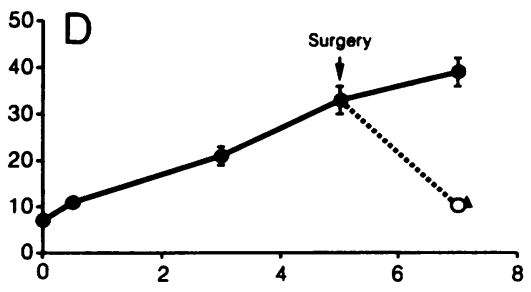

Figure 1. Changes in $(A)$ body weight; $(B)$ $\mathrm{Ca}^{2+} ;(C)$ white blood cell (WBC) count; and $(D)$ spleen index. At each time point, animals were anesthetized, their body weight, $\mathrm{Ca}^{2+}$, and leukocyte count measured as described in Methods, and subsequently killed to remove spleens. (Closed circle) sham-operated; (open circle) tumor-excised; (closed triangle) nontumor-bearing nude mice. Each point represents mean $\pm \mathrm{SE}(n=6)$.

calcemia, leukocytosis, and cachexia (Fig. 1). For comparison, we examined nude mice carrying a similar tumor (OKK) also derived from a squamous cell carcinoma of the human maxilla but not associated with any of these paraneoplastic syndromes. In these nude mice, there was no evidence of cachexia, hypercalcemia, or leukocytosis and the spleen index was not signifcantly increased compared with non-tumor-bearing animals (Table I).

Surgical removal of $M H-85$ tumors. Surgical excision of MH-85 tumors from nude mice led to an increase in body weight, and a decrease in the $\mathrm{Ca}^{2+}$ and in the white cell count. In addition to these changes, there was also a striking decrease in splenic size (Fig. 1). These data indicate that the increase in splenic size is due to a circulating tumor product.

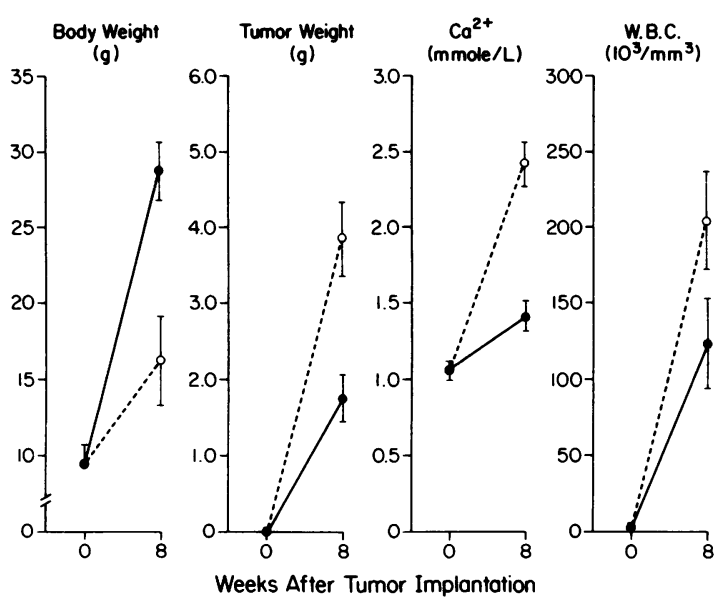

Figure 2. Effects of splenectomy before $\mathrm{MH}-85$ tumor implantation on changes in body weight, tumor weight, $\mathrm{Ca}^{2+}$, and WBC count in nude mice. Spleens of nude mice were surgically removed. $7 \mathrm{~d}$ after the surgery, the animals were implanted with the MH-85 tumor (time 0 ) and killed after 8 wk of tumor implantation. (Open circle) sham-operated; (closed circle) splenectomized nude mice. Values at 8 wk are mean $\pm \mathrm{SE}(n=8)$.
Splenectomy. When splenectomy was performed $7 \mathrm{~d}$ before tumor implantation, subsequent development of tumors was slower and resulted in tumors that were smaller than those in sham-operated animals (Fig. 2). There was a corresponding lesser increase in $\mathrm{Ca}^{2+}$ and in white blood cell count and lesser decrease in body weight.

In MH-85-bearing nude mice that were splenectomized 6 wk after tumor implantation, we found that there was no significant change in tumor size over the following $14 \mathrm{~d}$ (Fig. 3). However, there was markedly less decrease in body weight, and less increases in $\mathrm{Ca}^{2+}$ and white blood cell count.

Injection of freshly isolated normal nude mice spleen cells into splenectomized $\mathrm{MH}-85$-bearing nude mice. To confirm that the spleen was the source of factors that were important in

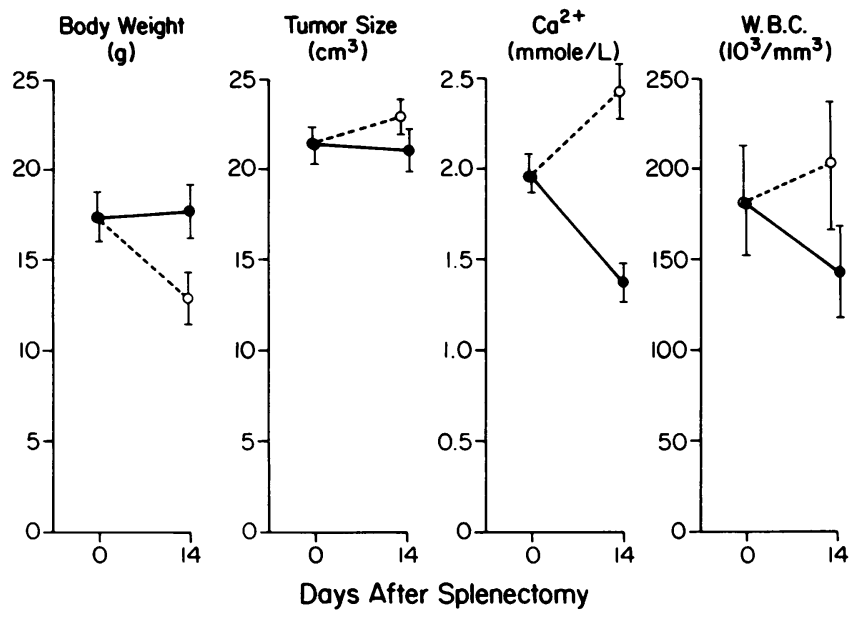

Figure 3. Effects of splenectomy on changes in body weight, tumor size, $\mathrm{Ca}^{2+}$, and WBC count in MH-85 bearing nude mice. 6 wk after MH-85 tumor implantation, spleens were surgically removed from MH-85 tumor-bearing animals. $14 \mathrm{~d}$ after the surgery, body weight, tumor size, $\mathrm{Ca}^{2+}$, and WBC were determined in (open circle) shamoperated; (closed circle) splenectomized nude mice. Values at $14 \mathrm{~d}$ are mean $\pm \operatorname{SE}(n=8)$. 

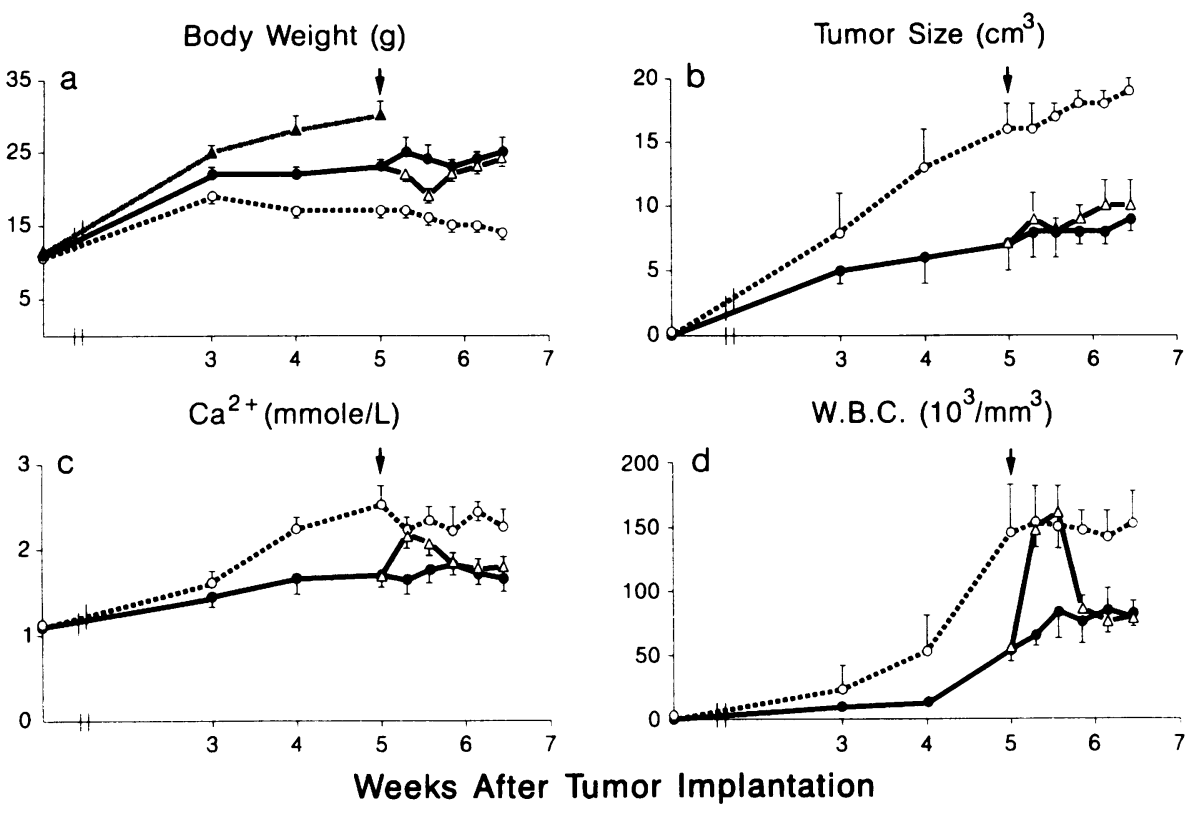

Figure 4. Effects of intravenous injection of freshly-isolated spleen cells on $(a)$ body weight; $(b)$ tumor size; $(c) \mathrm{Ca}^{2+} ;$ and $(d)$ WBC count. Spleens were surgically removed $7 \mathrm{~d}$ before MH- 85 tumor implantation. After 5 wk of tumor implantation, splenectomized $\mathrm{MH}-85$-bearing nude mice received freshly isolated normal nude mice spleen cells $\left(2 \times 10^{7}\right)$ in 0.1 $\mathrm{ml}$ PBS(-) from caudal vein (arrows). (Open circle) sham-operated and MH-85bearing; (closed circle) splenectomized and MH-85-bearing; (open triangle) splenectomized and $\mathrm{MH}-85$-bearing nude mice that received an intravenous injection of spleen cells; (closed triangle with broken line) non-tumor-bearing nude mice. Values are mean $\pm \operatorname{SE}(n=6)$.

the pathophysiology of these paraneoplastic syndromes, we performed splenectomy $7 \mathrm{~d}$ before tumor implantation and then $5 \mathrm{wk}$ later, injected freshly isolated spleen cells from nontumor-bearing nude mice intravenously into these splenectomized MH-85 tumor-bearing animals. Injection of spleen cells into splenectomized MH-85-bearing nude mice resulted in immediate and transient enhancement of hypercalcemia (Fig. 4 $c$ ), leukocytosis (Fig. $4 d$ ), and cachexia (Fig. $4 a$ ). Injection of spleen cells had no significant effect on tumor size (Fig. $4 \mathrm{~b}$ ).

Plasma TNF levels in MH-85-bearing nude mice. Since cachexia is also such a striking component of this tumor model, we measured TNF concentrations in the plasma by radioimmunoassay. We found that levels of TNF were increased almost fourfold compared with control non-tumor-bearing animals (Table II). The circulating TNF levels were comparable to those found in nude mice carrying TNF-secreting Chinese hamster ovary cells (26). The plasma TNF levels in OKK tumor-bearing nude mice were the same as in non-tumor-bearing nude mice (Table II). These results are consistent with the hypothesis that TNF was responsible for the hypercalcemia and cachexia associated with the MH-85 tumor.
Effect of TNF $\mathrm{Ab}$ on $\mathrm{Ca}^{2+}$ levels in $\mathrm{MH}$-85-bearing nude mice. To test this hypothesis we injected neutralizing TNF Ab into hypercalcemic and cachectic nude mice bearing $\mathrm{MH}-85$ tumors. As depicted in Fig. $5 a$, daily injection of the TNF Ab ( $1 / 5$ diluted) for $4 \mathrm{~d}$ into $\mathrm{MH}-85$-bearing hypercalcemic nude mice resulted in a dramatic decrease in $\mathrm{Ca}^{2+}$ levels. This began after 3-4 d of TNF Ab injections, continued to fall for a further 3-4 d, and remained suppressed for a further $3 \mathrm{~d}$ after TNF Ab injections were discontinued but then began to increase (Fig. 5 a). Injection of NIS in an identical manner failed to affect $\mathrm{Ca}^{2+}$ levels (Fig. $5 \mathrm{~b}$ ). However, subsequent administration of the TNF $A b$ to the same animals caused a significant decrease in the $\mathrm{Ca}^{2+}$ levels (Fig. 5 b). The TNF Ab did not alter $\mathrm{Ca}^{2+}$ levels in OKK- or non-tumor-bearing nude mice (Fig. 5, $c$ and $d$ ).

Histological examination of calvariae from mice bearing MH-85 tumors and injected with TNF Ab revealed marked suppression of osteoclast activity compared with mice not treated with the antibodies (Fig. 6, $a$ and $b$ ).

Effects of TNF Ab on body weight and leukocyte count. In another experiment, we injected TNF Ab into cachectic, hypercalcemic, and neutrophilic nude mice bearing $\mathrm{MH}-85$ tu-

Table II. Body Weight, Ca ${ }^{2+}$ Levels, and Plasma TNF Levels in Nude Mice Bearing MH-85 Tumors 8 Wk Posttransplantation

\begin{tabular}{|c|c|c|c|c|c|c|c|}
\hline & \multirow[b]{2}{*}{ Weeks } & \multicolumn{2}{|c|}{ Carcass weight } & \multicolumn{2}{|c|}{$\mathrm{Ca}^{2+}$} & \multicolumn{2}{|c|}{ Plasma TNF } \\
\hline & & 0 & 8 & 0 & 8 & 0 & 8 \\
\hline & $n$ & \multicolumn{2}{|c|}{$g$} & \multicolumn{2}{|c|}{ mmol/liter } & \multicolumn{2}{|c|}{$p g / m l$} \\
\hline \multicolumn{8}{|c|}{ Nude mouse bearing } \\
\hline None & 6 & $5 \pm 0.2$ & $29 \pm 2$ & $0.90 \pm 0.03$ & $0.88 \pm 0.03$ & ND & $242 \pm 29$ \\
\hline MH-85 tumors & 6 & $5 \pm 0.1$ & $14 \pm 5^{*}$ & $0.98 \pm 0.07$ & $2.17 \pm 0.24^{\ddagger}$ & ND & $804 \pm 63^{\ddagger}$ \\
\hline OKK tumors & 5 & $5 \pm 0.2$ & $28 \pm 4$ & $0.91 \pm 0.06$ & $1.03 \pm 0.05$ & ND & $291 \pm 43$ \\
\hline
\end{tabular}

Mean \pm SE. * Significantly smaller than non-tumor- or OKK-bearing animals $(P<0.01)$. ${ }^{\ddagger}$ Significantly higher than non-tumor- or OKKbearing animals $(P<0.01)$. ND, not determined. 


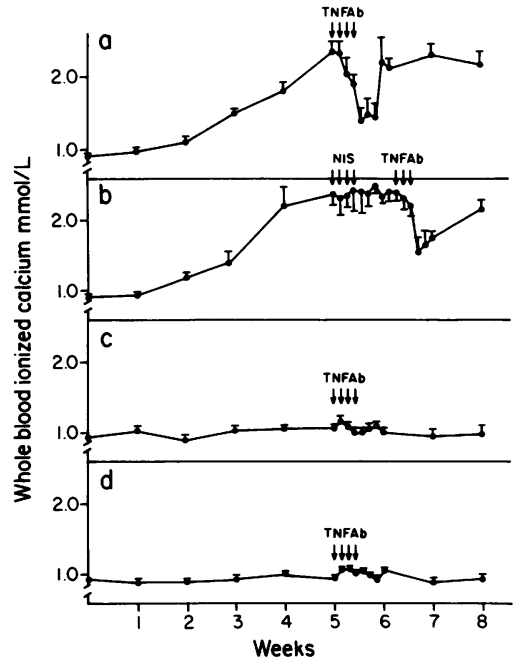

Figure 5. Changes in $\mathrm{Ca}^{2+}$ levels before and after injection of TNF $\mathrm{Ab}$ into $(a$ and $b) \mathrm{MH}-$ 85 -bearing $(n=6$ and 6); (c) OKK-bearing ( $n$ $=4)$; $(d)$ non-tumorbearing nude mice ( $n$ $=12$ ). $1 / 5$ diluted TNF $\mathrm{Ab}$ was injected intraperitoneally daily for 4 $\mathrm{d}$ as indicated by arrows in the figure. Weeks, weeks after MH-85 tumor inoculation. Values are expressed as means \pm SE.

mors at a higher concentration and for a longer period. We found significant increases in body weight (Fig. $7 a$ ) and marked decreases in $\mathrm{Ca}^{2+}$ (Fig. $7 b$ ) by injecting undiluted TNF Ab every $2 \mathrm{~d}$ for $18 \mathrm{~d}$, indicating that animals recovered from cachexia and hypercalcemia. These anticachectic and antihypercalcemic effects of TNF Ab lasted for 2 wk even after discontinuation of TNF Ab injection. The leukocyte count was also significantly decreased by injection of TNF Ab (Table III). However, TNF Ab failed to normalize body weight, $\mathrm{Ca}^{2+}$, and leukocyte count. This suggests that other cytokines such as CSFs and IL-1 also play roles in the pathophysiology of cachexia, hypercalcemia, and leukocytosis. Alternatively, injection of TNF Ab every $2 \mathrm{~d}$ for $18 \mathrm{~d}$ might not be enough to obtain complete recovery from these paraneoplastic syndromes. Injection of NIS showed no effect on body weight (data not shown) and leukocyte count (Table III). Apparent tumor size did not change before or after TNF Ab injection (data not shown).

Cellular source of elevated plasma TNF. The results show that TNF concentrations were increased in the plasma of these tumor-bearing nude mice and caused hypercalcemia, leukocytosis, and cachexia, but they do not indicate the source of the TNF. We examined CM harvested from cultured MH-85 cells and $\mathrm{MH}-85$ cell lysate on a number of occasions but could never detect TNF activity (data not shown). TNF is a macrophage product (27-29). We therefore thought it likely that the elevated levels of TNF in MH-85-bearing nude mice were due to excessive production by host cells of the monocyte-macrophage family in response to factors released by the MH-85 tumor. As shown in Table IV, CM harvested from MH-85 tumor cell cultures stimulated TNF production by human peripheral blood monocytes, the promyelocytic leukemia cell line HL-60 (22), and the monoblastic cell line U937 (23). The CM also increased TNF release by spleen mononuclear cells and peritoneal macrophages from non-tumor- and $\mathrm{MH}-85$-bearing nude mice. Cells from MH-85-bearing nude mice secreted higher concentrations of TNF than did cells from non-tumor-bearing animals. Cytotoxic activity of the culture supernatants on L929 cells was completely neutralized with anti-human or antimouse TNF antibodies (data now shown). Incubation of cells with CMs alone did not induce any TNF secretion. The stimu- latory effect of CM was dose- and time-dependent (data not shown). Endotoxin was assayed in CM by the limulus amebocyte lysate assay using a commercial kit (Sigma) but was not present in sufficient quantities to induce TNF release. In addition, polymyxin B $(20 \mu \mathrm{g} / \mathrm{ml})$, which inhibits endotoxin activity (30), did not block the induction of TNF secretion by CM (data not shown). CM harvested from OKK cells had no effect on any of the cells in the monocyte lineage examined.

\section{Discussion}

In this study, we found that splenectomy causes dramatic effects on the growth of a human squamous cell carcinoma in nude mice, as well as on three paraneoplastic syndromes associated with this tumor. The effects of splenectomy on the paraneoplastic syndromes were not due simply to a change in tumor bulk, because splenectomy was performed in some animals without a change in tumor size but still with alleviation of the paraneoplastic syndromes. The most likely explanation for our findings is that the spleen in $\mathrm{MH}-85$ tumor-bearing mice was the source of a humoral factor or factors that were responsible for the paraneoplastic syndromes. In experiments in which spleen cells were injected back into the MH-85 tumor-bearing nude mice that had been splenectomized, the paraneoplastic syndromes were immediately enhanced. Since the spleen did not contain tumor cells, this suggested that normal host cells were the source of these factors. The spleen is a major hematopoietic organ in the mouse (31) and contains granulocytes, monocytes, and lymphocytes. Thus, it is likely that cytokines produced by splenic host immune cells were responsible for these paraneoplastic syndromes. Likely candidates for such cytokines include IL-1 and TNF, both of which have been associated with each of the paraneoplastic syndromes of hypercalcemia $(26,32,33)$, leukocytosis $(34,35)$ and cachexia $(36)$, as well as with effects on tumor growth (37).

From the work of Beutler, Cerami, and their colleagues (29, 38) and the study reported by Oliff et al. (36), we felt it possible that TNF may play an important role in the cachexia associated with this tumor model. However, TNF might not be the only mediator, since elevated circulating levels have not always been found in experimental animals and patients with cachexia and malignancy $(39,40)$. Potential roles of TNF in other paraneoplastic syndromes still remain to be elucidated. TNF has been shown to stimulate bone resorption both in vitro (41) and in vivo $(26,42)$ and to increase plasma calcium in vivo $(26,32)$. In this study, we have found that plasma levels of TNF in MH-85-bearing nude mice were elevated almost fourfold above those of control animals (Table II) and that TNF Ab significantly decreased osteoclastic bone resorption and $\mathrm{Ca}^{2+}$ levels (Figs. 5 and 6). These results indicate the importance of TNF in the pathogenesis of the hypercalcemic syndrome and suggest a link between hypercalcemia and cachexia in this tumor model. Furthermore, the data presented in Table IV suggest that increased circulating levels of TNF in the MH-85bearing nude mouse are due not to overproduction by tumor cells but originate from host immune cells that are stimulated by soluble factors released by the tumor. Since previous studies on the mechanism of cancer-associated hypercalcemia have focused on systemic and/or local factors produced directly by the tumors (43), our results provide an additional mechanism 

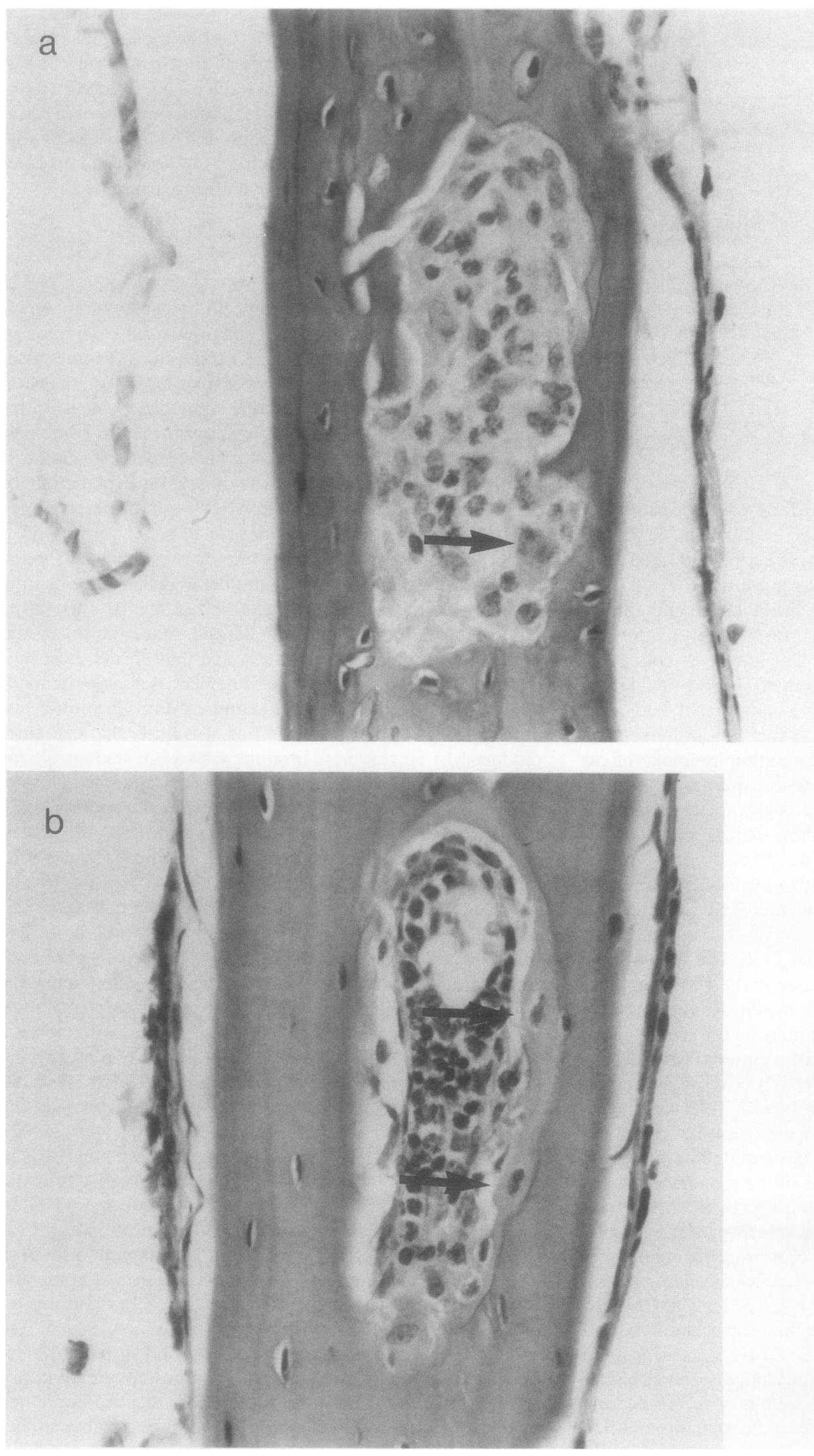

Figure 6. Histological examination of calvarial bones from $(a)$ mice bearing $\mathrm{MH}-85$ tumors, and $(b)$ mice bearing $\mathrm{MH}-85$ tumors after injection of neutralizing TNF Ab, as described in the text. In tumorbearing mice not injected with TNF $\mathrm{Ab}(a)$, there was active osteoclastic bone resorption and resorption surfaces, as indicated by the arrows. In the tumor-bearing mice treated with TNF Ab $(b)$, there was a marked decrease in osteoclast numbers and less prominent marrow space, accompanied by new bone formation (arrows). Calvariae were examined $3 \mathrm{~d}$ after the final injection of TNF Ab, at which time $\mathrm{Ca}^{2+}$ levels were the lowest (see Fig. $5 a)$. 


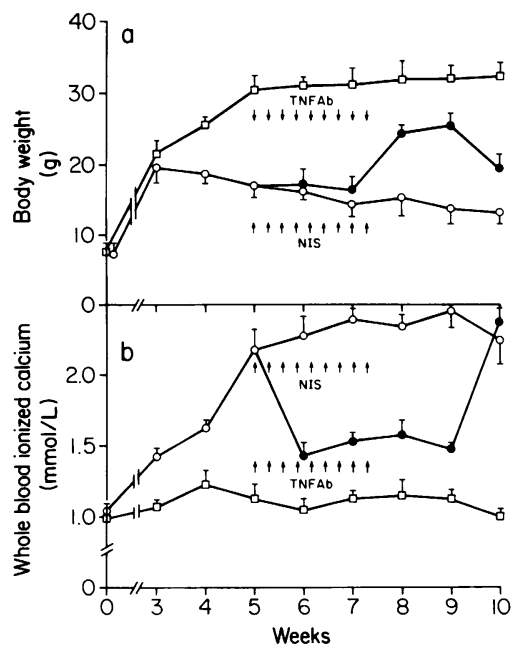

Figure 7. Changes in body weight $(a)$ and $\mathrm{Ca}^{2+}$ levels $(b)$ before and after injection of TNF $\mathrm{Ab}$ into $\mathrm{MH}-85$ bearing nude mice. Undiluted TNF Ab was injected intraperitoneally every $2 \mathrm{~d}$ for 18 $\mathrm{d}$ as indicated by arrows in the figure. (Open square) age-matched non-tumor-bearing animals; (open circle) MH-85 tumor-bearing nude mice treated with NIS; (closed circle) MH-85 tumor-bearing nude mice treated with

$\mathrm{TNF} \mathrm{Ab}$. Values are expressed as means $\pm \mathrm{SE}$ ( $n=6$ for each group).

underlying the pathophysiology of the hypercalcemia of malignancy.

If this hypothesis is correct, then it would be of interest to determine the identity of the tumor product that was responsible for promoting splenic cells to release cytokines. In two similar tumor models, both of which are associated with hypercalcemia and cachexia, we found that host immune cells release TNF and that circulating TNF is increased in tumor-bearing animals. These are the A375 human melanoma and the rat Leydig cell tumor. We have examined tumor cell-conditioned media harvested from A375 cells and found that the factor released by the tumor cells responsible for TNF production is GM-CSF (44). Others had previously shown that GM-CSF stimulates TNF production by immune cells $(21,45-47)$. However, the TNF-inducing factor produced by MH-85 cells is unlikely to be GM-CSF, since it is not removed from conditioned media by GM-CSF affinity columns and is not blocked by GMCSF neutralizing antibodies. Moreover, it does not elute with authentic GM-CSF on ion exchange columns or HPLC columns. The activity is also not neutralized by antibodies to GCSF, M-CSF, IL- $1 \alpha$ and $\beta$, IL-6, leukemia inhibitory factor, and interferon-gamma. We are currently attempting to identify this soluble mediator.

Table III. Effect of TNF Ab on Leukocyte Count in MH-85-bearing Nude Mice

\begin{tabular}{|c|c|c|}
\hline \multirow[b]{2}{*}{ Treatment } & \multicolumn{2}{|c|}{ Leukocyte count } \\
\hline & Before & After \\
\hline & \multicolumn{2}{|c|}{$10^{3} / \mathrm{mm}^{3}$} \\
\hline NIS & $480 \pm 29$ & $470 \pm 43$ \\
\hline TNF Ab & $470 \pm 27$ & $260 \pm 29^{*}$ \\
\hline
\end{tabular}

$0.1 \mathrm{ml} 1 / 5$ diluted TNF Ab or NIS was injected intraperitoneally every day for $5 \mathrm{~d}$ to nude mice bearing $\mathrm{MH}-85$ tumor for $8 \mathrm{wk} .2 \mathrm{~d}$ after final injection of TNF Ab or NIS, leukocyte count was determined. Leukocyte count in age-matched non-tumor-bearing nude mice is $7 \pm 2 \times 10^{3} / \mathrm{mm}^{3}$. Values are shown as mean $\pm \mathrm{SE}(n=6)$. * Significantly smaller than NIS-treated group $(P<0.01)$.
Table IV. Secretion of TNF by Immune Cells in Response to $\mathrm{MH}-85 \mathrm{CM}$

\begin{tabular}{|c|c|c|c|}
\hline \multirow[b]{2}{*}{ Cells } & \multicolumn{3}{|c|}{$\begin{array}{l}\text { TNF secretion }(\mathrm{U} / \mathrm{ml}) \text { in cultures } \\
\text { treated with PMA and }\end{array}$} \\
\hline & $\begin{array}{l}\text { Control } \\
\text { medium }\end{array}$ & MH-85 CM & OKK CM \\
\hline \multicolumn{4}{|l|}{ Non-tumor-bearing nude mice } \\
\hline Spleen mononuclear cells & $2 \pm 1$ & $49 \pm 3^{*}$ & $3 \pm 1$ \\
\hline Peritoneal macrophages & $2 \pm 1$ & $196 \pm 12^{*}$ & $3 \pm 1$ \\
\hline \multicolumn{4}{|l|}{ MH-85-bearing nude mice } \\
\hline Spleen mononuclear cells & $48 \pm 5^{\ddagger}$ & $522 \pm 52^{* . \ddagger}$ & $33 \pm 3$ \\
\hline Peritoneal macrophages & $6 \pm 1^{\ddagger}$ & $871 \pm 66^{*, \pm}$ & $9 \pm 1$ \\
\hline \multicolumn{4}{|l|}{ Human } \\
\hline Peripheral blood monocytes & $12 \pm 1$ & $412 \pm 36^{*}$ & $11 \pm 1$ \\
\hline HL-60 & $3 \pm 1$ & $52 \pm 3^{*}$ & $3 \pm 1$ \\
\hline U937 & $3 \pm 1$ & $636 \pm 49^{*}$ & $5 \pm 1$ \\
\hline
\end{tabular}

Mean \pm SE.

Cells were cultured in the presence of PMA $(10 \mathrm{ng} / \mathrm{ml})$ and control or tumor CM $(50 \%$, vol/vol) for $24 \mathrm{~h}$. The supernatants harvested from these cultures were assayed in triplicate for their TNF biological activity by serial dilution using the cytotoxicity bioassay described in the text. The same experiments were carried out several times and always reproduced similar results. Data shown are from the most representative experiment.

* Significantly higher than control- or OKK-CM-treated group ( $P$ $<0.001$ ).

${ }^{\ddagger}$ Significantly higher than non-tumor-bearing nude mice $(P<0.005)$.

These three paraneoplastic syndromes of hypercalcemia, leukocytosis, and cachexia may occur together more frequently than could be expected by chance alone. This would be understandable if the mechanism responsible was due to a tumor product stimulating secretion of cytokines by host immune cells. In a recent survey of 225 patients with cancers of the oral cavity, we found 11 patients with hypercalcemia and 10 patients with leukocytosis, and 5 of these patients had the combination of both syndromes (47a). Hypercalcemia and leukocytosis have frequently been reported to occur together, particularly in Japanese patients with tumors of the oral cavity, head, and neck $(6-8,10)$. This association is of particular interest because granulocytes and osteoclasts likely share a common hematopoietic precursor in the bone marrow (48), and a tumor-associated factor that stimulates formation of granulocytes may also stimulate formation of osteoclasts. Cytokines such as TNF and IL-1 have been shown to induce osteoclast formation (49) and to cause granulocytosis $(34,35)$. The association with leukocytosis is complex because of the evidence that GM-CSF, which can induce TNF and IL-1 production by normal immune cells $(21,50)$, also causes granulocytosis in vivo $(51,52)$. MH-85 cells in fact produce small amounts of GMCSF, although our data suggest that this is not the major factor responsible for TNF production.

Another intriguing effect of splenectomy to be noted is that MH-85 tumor growth was retarded in nude mice that had splenectomy before tumor implantation. Impaired host immune responses due to increased numbers of suppressor cells in spleens of tumor-bearing animals have been demonstrated (53-56). Recently, GM-CSF produced by a murine mammary adenocarcinoma has been found to increase a number of sup- 
pressor cells in spleen (15). Thus, diminished tumor growth in splenectomized $\mathrm{MH}-85$-bearing animals is presumably due to elimination of splenic suppressor cells which in turn result in enhancement of host immune surveillance.

We do not know if our results have significance for the treatment of difficult paraneoplastic syndromes associated with cancer. However, it has been demonstrated that splenectomy is beneficial in various hematologic disorders $(57,58)$ and particularly relevant to our results is that splenectomy in patients with hairy cell leukemia dramatically improves severe hematopoietic failure (59) that is likely to be due to inappropriate secretion of TNF by host immune cells (60). Therefore, although spleen is not the only source of immune cells involved in cytokine production, we believe that our results have at least some implications for the pathophysiology of paraneoplastic syndromes associated with cancer, and suggest that host immune cells that produce cytokines as part of the immune response to the presence of a tumor may be involved.

\section{Acknowledgments}

We are grateful to Nancy Garrett and Thelma Barrios for their expert secretarial help in the preparation of this manuscript. This work was supported in part by grants RR-1346, AR-28149, CA-40035, and DE08569.

\section{References}

1. Bunn, P. A., and J. D. Minna. 1985. Paraneoplastic syndromes. In Cancer Principles and Practice of Oncology. V. T. De Vita, S. Hellman, and S. A. Rosenberg, editors. J. B. Lippincott Co., Philadelphia. 1797-1842.

2. Abeloff, M. D. 1987. Paraneoplastic syndromes. A window of the biology of cancer. N. Engl. J. Med. 317:1598-1600.

3. Norton, J. A., J. L. Peakock, and S. D. Morrison. 1987. Cancer cachexia. Crit. Rev. Oncol./Hematol. 7:289-327.

4. Mundy, G. R., and T. J. Martin. 1982. The hypercalcemia of malignancy. Pathogenesis and treatment. Metab. Clin. Exp. 31:1247-1277.

5. Shoenfeld, Y., A. Tal, S. Berliner, and J. Pinkhas. 1986. Leukocytosis in non-hematological malignancies: a possible tumor-associated marker. J. Cancer Res. Clin. Oncol. 111:54-58.

6. Saito, K., Y. Kuratomi, K. Yamamoto, T. Saito, T. Kuzuya, S. Yoshida, S. Moriyama, and A. Takahashi. 1981. Primary squamous cell carcinoma of the thyroid associated with marked leukocytosis and hypercalcemia. Cancer (Phila.). 48:2080-2083.

7. Kondo, Y., K. Sato, H. Ohkawa, Y. Ueyama, T. Okabe, N. Sato, S. Asano M. Mori, N. Ohsawa, and K. Kosaka. 1983. Association of hypercalcemia with tumors producing colony-stimulating factor(s). Cancer Res. 43:2368-2374.

8. Sato, K., H. Mimura, D. C. Han, T. Kakiuchi, Y. Ueyama, H. Ohkawa, T. Okabe, Y. Kondo, N. Ohsawa, T. Tsushima, and K. Shizume. 1986. Production of bone-resorbing activity and colony-stimulating activity in vivo and in vitro by a human squamous cell carcinoma associated with hypercalcemia and leukocytosis. J. Clin. Invest. 78:145-154.

9. Lee, M. Y., C. C. Liu, J. L. Lottsfeldt, S. A. Judkins, and G. A. Howard. 1987. Production of granulocyte-stimulating and bone cell modulating activities from a neutrophilia, hypercalcemia-inducing murine mammary cancer cell line. Cancer Res. 47:4059-4065.

10. Yoneda, T., N. Nishikawa, R. Nishimura, I. Kato, and M. Sakuda. 1989. Three cases of oral squamous cancer associated with leukocytosis, hypercalcemia, or both. Oral Surg. Oral Med. Oral Pathol. 68:604-611.

11. Bateman, J. C. 1951. Leukemoid reactions to transplanted mouse tumors. J. Nat. Cancer Inst. 11:671-688.

12. Lappat, E. J., and M. Cawein. 1964. A study of the leukemoid response to transplantable A-280 tumor in mice. Cancer Res. 24:302-311.

13. Sato, N., S. Asano, Y. Ueyama, M. Mori, T. Okabe, Y. Kondo, N. Ohsawa, and K. Kosaka. 1979. Granulocytosis and colony-stimulating activity (CSA) produced by a human squamous cell carcinoma. Cancer (Phila.). 43:605610.

14. Ishikawa, M., M. Hosokawa, N. Oh-hara, N. Yoshiyuki, and H. Kobayashi. 1987. Marked granulocytosis in C57 BL/6 mice bearing a transplanted BMT 11 fibrosarcoma. J. Nat. Cancer Inst. (Bethesda). 78:567-571.

15. Fu, Y., G. Watson, J. J. Jimenez, Y. Wang, and D. M. Lopez. 1990.
Expansion of immunoregulatory macrophages by granulocyte-macrophage colony-stimulating factor derived from a murine mammary tumor. Cancer Res. 50:227-234

16. Jensen, F. C., R. B. L. Gwatkin, and J. D. Biggers. 1964. A simple method which allows simultaneous isolation of specific types of cells. Exp. Cell Res. 34:440-447.

17. Frindel, E. L., E. P. Malaise, E. Alpen, and M. Tubiana. 1967. Kinetics of cell proliferation of an experimental tumor. Cancer Res. 27:1122-1131.

18. Yoneda, T., T. B. Aufdemorte, R. Nishimura, N. Nishikawa, M. Sakuda, M. M. Alsina, J. B. Chavez, and G. R. Mundy. 1991. Occurrence of hypercalcemia and leukocytosis with cachexia in a human squamous cell carcinoma of the maxilla in athymic nude mice. A novel experimental model of 3 concomitant paraneoplastic syndromes. J. Clin. Oncol. In press.

19. Yates, A. J. P., G. E. Gutierrez, P. Smolens, P. S. Travis, M. S. Katz, T. B. Aufdemorte, B. F. Boyce, T. K. Hymer, J. W. Poser, and G. R. Mundy. 1988 Effects of a synthetic peptide of a parathyroid hormone-related protein on calcium homeostasis, renal tubular calcium reabsorption, and bone metabolism in vivo and in vitro in rodents. J. Clin. Invest. 81:932-938.

20. Williams, D. M., L. Bonewald, G. D. Roodman, G. I. Byrne, M. D. Magee, and J. Schachter. 1989. Tumor necrosis factor alpha is a cytotoxin induced by murine Chlamydia trachomatis infection. Infect. Immun. 57:13511355 .

21. Cannistra, S. A., A. Rambaldi, D. R. Spriggs, F. Herrmann, D. Kufe, and J. D. Griffin. 1987. Human granulocyte-macrophage colony-stimulating factor induces expression of the tumor necrosis factor gene by the U937 cell line and by normal human monocytes. J. Clin. Invest. 79:1720-1728.

22. Collins, S. J. 1987. The HL-60 promyelocytic leukemia cell line: proliferation, differentiation, and cellular oncogene expression. Blood. 70:1233-1244.

23. Sundstrom, C., and K. Nilsson. 1976. Establishment and characterization of a human histiocytic lymphoma cell line (U-937). Int. J. Cancer. 17:565-577.

24. Kawakami, M., P. H. Pekala, M. D. Lane, and A. Cerami. 1982. Lipoprotein lipase suppression in 3T3-L1 cells by an endotoxin-induced mediator from exudate cells. Proc. Natl. Acad. Sci. USA. 79:912-916.

25. Aggarwall, B. B., W. J. Kohr, P. E. Hass, B. Moffat, S. A. Spencer, W. J. Henzel, T. S. Bringman, G. E. Nedwin, D. V. Goeddel, and R. N. Harkins. 1985 Human tumor necrosis factor. Production, purification, and characterization. $J$. Biol. Chem. 260:2345-2354.

26. Johnson, R. A., B. F. Boyce, G. R. Mundy, and G. D. Roodman. 1989. Tumors producing human TNF induce hypercalcemia and osteoclastic bone resorption in nude mice. Endocrinology. 124:1424-1427.

27. Carswell, E. A., L. J. Old, R. L. Kassel, S. Green, G. N. Fiore, and B. Williamson. 1975. An endotoxin-induced serum factor that causes necrosis of tumors. Proc. Natl. Acad. Sci. USA. 72:3666-3670.

28. Old, L. J. 1988. Tumor necrosis factor. Sci. Am. 258:59-75.

29. Beutler, B., and A. Cerami. 1988. Tumor necrosis, cachexia, shock, and inflammation: a common mediator. Annu. Rev. Biochem. 57:505-518.

30. Jacobs, D. M., and D. C. Morrison. 1977. Inhibition of the mitogenic response to lipopolysaccharide (LPS) in mouse spleen cells by polymyxin B. $J$. Immunol. 118:21-27.

31. Hardy, C. L., and L. Balducci. 1985. Hemopoietic alterations of cancer. Am. J. Med. Sci. 290:196-205.

32. Tashjian, A. H., E. F. Voelkel, L. Maribeth, D. Goad, T. Bosma, and L. Levine. 1987. Tumor necrosis factor- $\alpha$ (cachectin) stimulates bone resorption in mouse calvaria via a prostaglandin-mediated mechanism. Endocrinology. 120:2029-2036.

33. Sabatini, M., B. Boyce, T. Aufdemorte, L. Bonewald, and G. R. Mundy. 1988. Infusions of recombinant human interleukin- $\alpha$ and $\beta$ cause hypercalcemia in normal mice. Proc. Natl. Acad. Sci. USA. 85:5235-5239.

34. Renick, D. G., J. Larrick, and S. L. Kunkel. 1986. Tumor necrosis factorinduced alterations in circulating leukocyte populations. Biochem. Biophys. Res. Commun. 141:818-824.

35. Ulich, T. R., J. Castilla, M. Keys, G. A. Granger, and R.-X. Ni. 1987. Kinetics and mechanisms of recombinant human interleukin-1 and tumor necrosis factor- $\alpha$-induced changes in circulating numbers of neutrophils and lymphocytes. J. Immunol. 139:3406-3415.

36. Oliff, A., D. Defea-Jones, M. Boyer, D. Martinez, D. Kiefer, G. Vuocola, A. Wolfe, and S. H. Socker. 1987. Tumors secreting human TNF/cachectin induce cachexia in mice. Cell. 50:555-563.

37. Le, J., and J. Vilcek. 1987. Tumor necrosis factor and interleukin 1: cytokines with multiple overlapping biological activities. Lab. Invest. 56:234248.

38. Moldawer, L. L., S. F. Lowry, and A. Cerami. 1989. Cachectin: its impact on metabolism and nutritional status. Annu. Rev. Nutr. 8:585-609.

39. Socher, S. H., D. Martinez, J. B. Craig, J. G. and A. Oliff. 1988. Tumor necrosis factor not detectable in patients with clinical cancer cachexia. $J$. Nat Cancer Inst. (Bethesda). 80:595-558.

40. Moldawer, L. L., J. Gelin, T. Scherstein, and K. G. Lundholm. 1987. Circulating interleukin 1 and tumor necrosis factor during inflammation. $\mathrm{Am}$. J. Physiol. 53:R922-R928.

41. Bertolini, D. R., G. E. Nedwin, T. S. Bringman, and G. R. Mundy. 1986 
Stimulation of bone resorption and inhibition of bone formation in vitro by human tumour necrosis factors. Nature (Lond.). 319:516-518.

42. König, A., R. C. Mühlbauer, and H. Fleisch. 1988. Tumor necrosis factor alpha and interleukin-1 stimulate bone resorption in vivo as measured by urinary $\left[{ }^{3} \mathrm{H}\right]$ tetracycline excretion from prelabeled mice. J. Bone Miner. Res. 3:621-627.

43. Mundy, G. R., K. J. Ibbottson, and S. M. D'Souza. 1985. Tumor products and the hypercalcemia of malignancy. J. Clin. Invest. 76:391-394.

44. Sabatini, M., J. Chavez, G. R. Mundy, and L. F. Bonewald. 1990. Stimulation of tumor necrosis factor release for monocytic cells by the A375 human melanoma via granulocyte-macrophage colony-stimulating factor. Cancer Res. 50:2673-2678.

45. Lindemann, A., D. Riedel, W. Oster, R. Mertelsmann, and F. Herrmann. 1988. Recombinant human granulocyte-macrophage colony-stimulating factor induces secretion of autoinhibitory monokines by U937 cells. Eur. J. Immunol. 18:369-374.

46. Wing, E. J., D. M. Magee, T. L. Whiteside, S. S. Kaplan, and R. K. Shadduck. 1989. Recombinant human granulocyte/macrophage colony-stimulating factor enhances monocyte cytotoxicity and secretion of tumor necrosis factor $\alpha$ and interferon in cancer patients. Blood. 73:643-646.

47. Heidenreich, S., J.-H. Gong, A. Schmidt, M. Nain, and D. Gemsa. 1989. Macrophage activation by granulocyte/macrophage colony-stimulating factor. Primary for enhanced release of tumor necrosis factor- $\alpha$ and prostaglandin $E_{2} . J$. Immunol. 143:1196-1205.

47a.Yoneda, T., R. Nishimura, I. Kato, M. Ohmae, M. Takita, and M. Sakuda. 1991. Frequency of the hypercalcemia-leukocytosis syndrome in oral malignancies. Cancer (Phila.). In press.

48. Mundy, G. R., and G. D. Roodman. 1987. Osteoclast ontogeny and function. In Bone and Mineral Research V. W. A. Peck, editor. Elsevier Science Publishers B. V., Amsterdam. 209-280.

49. Pfeilschifter, J., C. Chenu, A. Bird, G. R. Mundy, and G. D. Roodman. 1989. Interleukin- 1 and tumor necrosis factor stimulate the formation of human osteoclast-like cells in vitro. J. Bone Miner. Res. 4:113-118.

50. Sisson, S. D., and C. A. Dinarello. 1988. Production of interleukin-1 $\alpha$, interleukin- $1 \beta$ and tumor necrosis factor by human mononuclear cells stimu- lated with granulocyte-macrophage colony-stimulating factor. Blood. 72:13681374.

51. Donahue, R. E., E. A. Wang, D. K. Stone, R. Kamen, G. G. Wong, P. K. Sehgal, D. G. Nathan, and S. C. Clark. 1986. Stimulation of haematopoiesis in primates by continuous infusion of recombinant human GM-CSF. Nature (Lond.). 321:872-875.

52. Groopman, J. E., R. T. Mitsuyasu, M. J. De Leo, D. H. Oette, and D. W. Golde. 1987. Effect of recombinant human granulocyte-macrophage colonystimulating factor on myelopoiesis in the acquired immunodeficiency syndrome. N. Engl. J. Med. 317:593-598.

53. Kirchner, H., T. M. Chused, R. B. Herberman, H. T. Holden, and D. H. Lavrin. 1974. Evidence of suppressor cell activity in spleens of mice bearing primary tumors induced by Moloney sarcoma virus. J. Exp. Med. 139:14731487

54. Fujii, T., T. Igarashi, and S. Kishimoto. 1987. Significance of suppressor macrophages for immune-surveillance of tumor-bearing mice. J. Nat. Cancer Inst. (Bethesda). 78:509-517.

55. Almani, W. Y., P. J. Dolphin, R. L. Thies, W. R. McMaster, J. G. Levy, and B. L. Pope. 1988. Suppressor cell-inducing factor: a new lymphokine secreted by a natural suppressor cell line with natural cytotoxic activity. J. Immunol. 141:2529-2535

56. Nelson, D. S., and M. Nelson. 1987. Evasion of host defenses by tumor. Immunol. Cell. Biol. 65:287-304.

57. Scadden, D. T., L. I. Zon, and J. E. Groopman. 1989. Pathophysiology and management of HIV-associated hematologic disorders. Blood. 74:14551463.

58. Berchtold, P., and R. McMillan. 1989. Therapy of chronic idiopathic thrombocytopenic purpura in adults. Blood. 74:2309-2317.

59. Rosove, M. H., F. Naeim, S. Harwig, and J. Zighelboim. 1980. Severe platelet dysfunction in hairy cell leukemia with improvement after splenectomy. Blood. 55:903-906.

60. Lindeman, A., W.-D. Ludwig, W. Oster, R. Mertelsmann, and F. Herrmann. 1989. High-level secretion of tumor necrosis factor alpha contributes to hematopoietic failure in hairy cell leukemia. Blood. 73:880-884. 